\title{
Motivations for committed nature conservation action in Europe
}

DOI:

10.1017/S037689291700008X

\section{Document Version}

Accepted author manuscript

Link to publication record in Manchester Research Explorer

\section{Citation for published version (APA):}

Admiraal, J. F., van den Born, R., Beringer, A., Bonaiuto, F., Cicero, L., Hiedanpää, J., Knights, P., Knippenberg, L., Molinario, E., Musters, C. J. M., Naukkarinen, O., Polajnar Horvat, K., Popa, F., Smrekar, A., Soininen, T., Porras-Gomez, C., Soethe, N., Vivero Pol, J. L., \& de Groot, W. T. (2017). Motivations for committed nature conservation action in Europe. Environmental Conservation, 44(2), 148-157. [6]. https://doi.org/10.1017/S037689291700008X

\section{Published in:}

Environmental Conservation

\section{Citing this paper}

Please note that where the full-text provided on Manchester Research Explorer is the Author Accepted Manuscript or Proof version this may differ from the final Published version. If citing, it is advised that you check and use the publisher's definitive version.

\section{General rights}

Copyright and moral rights for the publications made accessible in the Research Explorer are retained by the authors and/or other copyright owners and it is a condition of accessing publications that users recognise and abide by the legal requirements associated with these rights.

\section{Takedown policy}

If you believe that this document breaches copyright please refer to the University of Manchester's Takedown Procedures [http://man.ac.uk/04Y6Bo] or contact uml.scholarlycommunications@manchester.ac.uk providing relevant details, so we can investigate your claim.

\section{OPEN ACCESS}




\section{Motivations for committed nature conservation action in Europe}

\section{Authors:}

J.F. ADMIRAAL ${ }^{1}$, R.J.G. VAN DEN BORN² ${ }^{2}$, A. BERINGER 3 , F. BONAIUTO ${ }^{4}$, L. CICERO $^{5}$, J. HIEDANPÄÄ ${ }^{6}$, P. KNIGHTS ${ }^{7}$, L.W.J. KNIPPENBERG ${ }^{2}$, E. MOLINARIO ${ }^{4}$, C.J.M. MUSTERS ${ }^{1}$, O. NAUKKARINEN ${ }^{6}, \mathrm{~K}^{2}$ POLAJNAR ${ }^{8}$, F. POPA ${ }^{9}$, A. SMREKAR ${ }^{8}$, T. SOININEN ${ }^{6}$, C. PORRAS-GOMEZ ${ }^{10}$, N. SOETHE ${ }^{3}$, J.L. VIVERO-POL ${ }^{10}$, W.T. DE $\mathrm{GROOT}^{2}$

${ }^{1}$ Institute of Environmental Sciences, Leiden University, P.O. Box 9518, 2300 RA Leiden, The Netherlands

${ }^{2}$ Institute of Science, Innovation and Society. Faculty of Science. Radboud University. P.O. Box 9010, 6500 GL Nijmegen, The Netherlands

${ }^{3}$ Institute of Botany and Landscape Ecology - Environmental Ethics. University of Greifswald, Soldmannstrasse 15, 17487 Greifswald, Germany

4Dipartimento di Psicologia dei Processi di Sviluppo e Socializzazione, Sapienza Università di Roma, Via dei Marsi, 78, 00185 Rome, Italy

${ }^{5}$ Department of Human Studies, LUMSA University, Piazza delle Vaschette 101, 00193

Rome, Italy

${ }^{6}$ Natural Resources Institute Finland, Itäinen Pitkäkatu 3, 20520 Turku, Finland.

${ }^{7}$ Philosophy, School of Social Sciences, The University of Manchester, Oxford Road, Manchester, M13 9PL, United Kingdom

${ }^{8}$ Anton Melik Geographical institute, Research Centre of Slovenian Academy of Sciences and Arts, P.P. 306, 1001 Ljubljana, Slovenia

${ }^{9}$ European Commission, DG Education and Culture, Rue de la Loi 200, B-1049 Brussels, Belgium

${ }^{10} \mathrm{BIOGOV}$, Centre for Philosophy of Law, College Thomas More, Université catholique de Louvain, Place Montesquieu 2 (Bte 15) B - 1348 Louvain-La-Neuve, Belgium

Keywords: Biodiversity conservation, ecosystem services, environmental policy, economic valuation

\section{Corresponding author:}

Name: J.F. Admiraal

Email: admiraal@cml.leidenuniv.nl

Telephone number: $31(0) 715275557$

Fax: +31 (0)71 5277434

Van Steenis gebouw

Einsteinweg 2

2333 CC Leiden 


\section{Summary}

Despite ongoing efforts to motivate politicians and publics in Europe for nature conservation, biodiversity continues to decline. Monetary valuation of ecosystem services appears to be insufficient to motivate people, suggesting that non-monetary values have a crucial role to play. There is insufficient information about the motivations of actors who have been instrumental in successful conservation projects. We investigated the motivations of these biodiversity actors for their work using a ranking of cards, and compared the results with the rankings of motivations of a second group of actors with more socially related interests. For both groups of actors, action for biodiversity was supported in general by two groups of motivations related to living a meaningful life and moral values. The non-biodiversity actors noted in addition that their action for biodiversity rested more on beauty, place attachment and intrinsic values in comparison with their main non-biodiversity interests. Our results have implications for environmental policy and biodiversity conservation in that the current tendency of focusing on economic valuation of biodiversity fails to address the motivations exhibited by successful actors, and thereby fails to motivate nature conservation on an individual level. 


\section{INTRODUCTION}

Biodiversity in Europe is in a crisis of continuous decline (EEA 2015). Biodiversity degradation is considered a serious topic by eight out of ten Europeans (EU 2015), yet this concern apparently is not translated into successful action (Pearce 2007). Attempts to address this problem now frequently take the approach of researching ecosystem services (e.g. MEA 2005) to inform private and public decision making. Ecosystem services as a concept attained a broader global institutionalization, as is visible for example in the global initiative TEEB (2013), large-scale research programmes such as IPBES (IPBES 2015) and the European Horizon 2020 (Admiraal et al. 2016), making ecosystem services the foremost way to express the value of biodiversity to society.

Nevertheless, the ecosystem services approach appears to fail in its motivational objective to halt further biodiversity degradation (Tittensor et al. 2014), which has prompted reflections on its limitations (O'Neill 1997; Norgaard 2010). Specifically, related economic approaches may crowd out other, non-economic motivations (Rode et al. 2015; Gómez-Baggethun \& Ruiz-Pérez 2011). Research from outside the ecosystem services community demonstrates that committed action for nature rests on grounds other than economic values, such as the development of trust between stakeholders and other moral standards (Hiedanpää \& Borgström 2014; Flint et al. 2013; Sponarski et al. 2014) and room for autonomous action in conservation initiatives (Dedeurwaerdere et al. 2016). 
Personal motivation to act for biodiversity is complex, but must be understood more fully to grasp where current efforts to motivate people fall short. Environmental psychology has conducted a large number of studies about motivation for environmental action, but this research is often focused on single factors assumed to be pivotal for action. Examples include connectedness to nature (Mayer \& Frantz 2004), egoistic, altruistic, and biospheric environmental concerns (Schultz 2001), place attachment (Williams \& Vaske 2003), community (Asah \& Blahna 2013), empathy (Schultz 2000), time perspective (Corral-Verdugo et al. 2006), views on human-nature relationships (Van den Born et al. 2001) and emotions, habits and rational choices (Carrus et al. 2008). These studies almost invariably conclude that the factors of interest perform a role in environmental behavior.

What remains unknown is how these factors act in concert or in relation to each other. Gifford \& Nilsson (2014) for example provide an overview of no less than 17 'categories of influence' on environmental behaviour, and conclude that research should focus on how these influences interact with each other. In search for theories of interaction, several studies depart from a relatively wide set of motivational factors. Kollmuss \& Agyeman (2002), for example, attempted to incorporate multiple factors, including knowledge, values, attitudes and emotions. Clark et al. (2001) and Ryan \& Deci (2000) distinguish between internal and external influences on behavior. Perkins (2010) combines several factors to measure people's emotional relationship with nature. These studies find that these factors are related to each other and that humans do not act for nature primarily to safeguard ecosystem services, but for a complex combination of reasons that is difficult to model. 
What motivates individuals to protect the environment therefore remains a key issue, and an interdisciplinary approach is needed for a better understanding of it (Perkins 2010). The present paper stands in this tradition of interdisciplinary, 'multi-factor studies', with the added value of focusing on a group of highly committed individuals as so-called 'biodiversity activists'. This group forms an important yet underexplored source of information about motivations to act for biodiversity.

Conservation motivations of committed 'biodiversity activists' likely differ from the motivations of other types of activists. In general, people may engage in conservation activities only in the margin of their lives, e.g. when donating to a conservation charity. Regarding motivations, a life-time devotion to biodiversity conservation might be driven by moral values while a marginal action might be motivated by a felt obligation or a social norm. Our research question was: how do committed actors for biodiversity rank their motivations to act for nature, given a broad set of motivational options? To clarify how the motivations of committed biodiversity actors might differ from non-biodiversity actors, we compare our 'biodiversity activists' to a group of counterpart activists who work with similar capacities and within similar work environments, but are committed to non-biodiversity related work. Mapping the specific motivations that both groups rank themselves would provide clarity that could help to stimulate both committed conservationists already working in the field and people acting for nature in the margin of their lives. 


\section{METHODS}

\section{Participant selection}

In Belgium, Finland, Germany, Italy, the Netherlands, Slovenia and the United Kingdom, biodiversity activists were identified and interviewed using the same methods to map their individual motivations for conservation action. The project recognized that motivation for biodiversity conservation can play out in many sectors of society, from managers making strategic decisions in business to elementary school teachers stimulating a wonder for nature in children. A list of three sectors with sub-categories was thus used as a criterion for selecting interviewees in each country. These sectors were $(I)$ the public domain (including local governments, city parks and projects part of Natura 2000 and UNESCO-MAB networks), (ii) business (including fishing, farming, forestry, food production, corporate land ownership and tourism) and (iii) civil society (including school teachers, NGOs, foundations, media professionals, civil activists). The categories were interpreted broadly in the search for interviewees, and were not intended for statistical analysis.

For each sub-category and country in the list, a 'biodiversity activist' was identified: a person who spends more time or energy for conservation than could be expected from job duties. Examples of such actions include founding a biodiversity NGO, radically greening a firm or spending tireless energy on nature education. The term biodiversity activist here includes many non-political actors, such as civil servants and school teachers. 
For the control group, actors were identified who worked in similar work environments, had similar capacities, abilities or opportunities to act as the biodiversity activists, but for other causes. In contrast, a random sample of the population would be less precise to test the factor of biodiversity as a topic for action, because too many other variables can be of major influence. Because of the diversity of backgrounds of the biodiversity activists, we searched, for each activist, for a specific non-biodiversity counterpart with a fittingly similar background in a similar work environment to the activist. Thus, pairs of interviewees were created that matched in as many factors as possible, with only the topic of biodiversity differing between them in their work. The founder of a biodiversityrelated foundation may therefore get as a counterpart the founder of a social-issue foundation, for such an individual may be the best match regarding similar capacities and a similar work environment for their actions.

The non-biodiversity actors nearly always reported strong motivations for other causes, often socially related. The first reason is that the fitting counterparts to the biodiversity activists also frequently worked in environments that predisposed them to be committed to certain goals, such as poverty reduction, projects for disabled people, community building or any other goal not directly related to biodiversity. Secondly, our interview structure forced interviewees to consider their main interests and passions. We took the factor 'activism' therefore as one of the matching characteristics between the biodiversity activists and the control group, while the topic biodiversity itself remained the differing factor. For simplicity's sake, we refer to the control group as 'non-biodiversity activists' here. 
Whilst selecting the biodiversity activists, most individuals turned out to be long-standing activists, male and with a high educational background. Since the search for counterparts to these activists happened pairwise, most counterparts had similar characteristics. We made a conscious effort to include female interviewees in both the activist and control groups when comparable candidates were found. In total, 217 interviewees took part in the cards ranking, of which 168 were male and 49 female; 109 of the 217 interviewees were classified as 'biodiversity activists' and 68 were classified as 'non-biodiversity activists'. For clarity of interpretations, forty interviewees were reclassified as not being part of either group, since the interviews showed that they did not report a clear commitment to any cause.

\section{Interview structure}

The interview consisted of a semi-structured life-history part, followed by a sorting of cards that displayed motivations. In the life-history part, the interviewees reflected on the history of their committed actions, in the context of their more general life story. For the cards sorting element, the life-history part acted as a 'primer', focusing the interviewees on their actions and developing a 'feel' for how their actions were embedded in the context of their life (see Table S1 for the interview structure). Subsequently, the interviewees were given a set of 20 cards in random order, with a motivation on one side and a brief explanation of the motivation on the other side (Table 1). The interviewees were asked to rank the cards for their actions on a 6-step scale from most important (6) to least important (1), and could freely distribute the motivations over the 6 levels. 
The procedure of the card rankings differed between the two groups in that the nonbiodiversity activists were asked to rank the cards twice: once for their non-biodiversity cause, their main cause defined by the interviewees themselves, and the second time for any biodiversity action they had engaged in. Their actions for biodiversity were usually fairly minor, e.g. making a small monthly donation to a conservancy. The resulting motivational rankings of both groups of actors allowed us to make three comparisons:

1. Motivations to act for biodiversity between both groups.

2. Motivations of the biodiversity activists to act for biodiversity on the one hand, and of the non-biodiversity activists to act for their main causes on the other.

3. Motivations within the group of non-biodiversity activists to act for their main cause and for biodiversity.

\section{Creating the motivation list}

The list of 20 motivations for the card set was grounded in a two-step, multi-disciplinary exploration that sought a representation of fundamental motivational concepts found in philosophy, social psychology and governance science. The first step was a literature review carried out by researchers of these disciplines and subsequently compiled into a reference document (BIOMOT 2013). The second step consisted of a four-day workshop involving all the researchers to create the list of motivations. These discussions were inspired by the professional experience and cultural diversity of the researchers, resulting in a list of 20 motivations that was considered 'saturated' (i.e. comprising all fundamental concepts). Representatives of all seven countries participated in discussions about the interpretations of the motivations in their own languages, and all 
researchers followed these during the interviews. The cards were translated and backtranslated as a control in the languages of the seven countries.

The concepts from the various disciplines appeared to overlap well in meaning; examples are the items of 'hedonic' in Schwartz (1992) and 'instrumental' in Muraca (2011), and the items of 'power' in Schwartz (1992) and 'control' in Fiske (2014). Another example of an overlap of concepts is that the concept of 'connectedness' was found in literature of different fields, including environmental psychology (Tam 2013) and philosophy (Nolt 2006). However, on the level of frameworks that authors tend to use to arrive at a structured classification, interdisciplinary convergence turned out to be impossible. For example, motivations can be grouped in classes such as intrinsic versus extrinsic, individually based versus group-based, or hedonic versus moral, but these classes could not be molded into a single structured classification. This is corroborated by Kollmuss \& Agyeman (2002) who encountered similar problems in combining models of environmental behavior. The card set thus represented values, emotional states and end goals, which could all be potential motivations. They were presented as an unstructured list (Table 1), open to be classified in follow-up studies depending on aim, research context or disciplinary tradition.

Due to coordination difficulties between partners, in three countries (Belgium, Finland and the UK) the non-biodiversity activists were asked to rank the cards only for their main cause, but the total numbers of the rankings in the entire dataset were still considered sufficient for the three comparisons. 
Table 1: the 20 motivations with a short description of each, as presented to the interviewees.

\begin{tabular}{|c|c|}
\hline Motivation & Given description on the card \\
\hline Curiosity and learning & $\begin{array}{l}\text { You are motivated by a fascination with complexity of things and the } \\
\text { opportunities they provide for learning. }\end{array}$ \\
\hline Living a worthwhile life & You are motivated by a desire to live a good, meaningful and worthwhile life. \\
\hline Future generations & $\begin{array}{l}\text { You are motivated by your care and concern for, or feeling of solidarity with, } \\
\text { future generations of humans. }\end{array}$ \\
\hline Value in itself & $\begin{array}{l}\text { You are motivated by a belief that some things are valuable in themselves, } \\
\text { regardless of their usefulness to you or others. }\end{array}$ \\
\hline $\begin{array}{l}\text { Pleasure of doing things with } \\
\text { others }\end{array}$ & You are motivated by the pleasure in joining in and collaborate with others. \\
\hline $\begin{array}{l}\text { Pleasure in doing what you are } \\
\text { good at }\end{array}$ & You are motivated by the pleasure in doing things that you are good at. \\
\hline Social benefit & $\begin{array}{l}\text { You are motivated by a desire to promote a benefit for your community or wider } \\
\text { society. }\end{array}$ \\
\hline My children/family & You are motivated by your care and concern for your children or family. \\
\hline Beauty & You are motivated by beauty or other aesthetic qualities. \\
\hline Connectedness & $\begin{array}{l}\text { You are motivated by a feeling of connectedness to something larger than } \\
\text { yourself and your feelings of care and affection for this larger whole. }\end{array}$ \\
\hline Attachment to place & You are motivated by your attachment to a particular place or places. \\
\hline Duty & You are motivated by a sense of duty, responsibility and/or obligation. \\
\hline To end conflict & You are motivated by a desire to end or prevent a collision between people. \\
\hline Self-significance & $\begin{array}{l}\text { You are driven by the desire to gain positive recognition from those around you, } \\
\text { because this makes your life more significant. }\end{array}$ \\
\hline Personal benefit & You are motivated by a desire to promote a benefit for yourself. \\
\hline Religion or spirituality & $\begin{array}{l}\text { You are motivated by a religious or spiritual belief or practice. (You are allowed } \\
\text { to choose between the two.) }\end{array}$ \\
\hline Control & You are motivated by a desire to have influence and to exercise that influence. \\
\hline Anger & $\begin{array}{l}\text { You are motivated by anger, disgust, contempt or other negative emotions } \\
\text { towards individuals, groups or events. }\end{array}$ \\
\hline Destiny/calling & You are motivated by a belief that you have a calling. \\
\hline Insecurity & $\begin{array}{l}\text { You are motivated by a sense of insecurity or anxiety and your desire to reduce } \\
\text { these feelings. }\end{array}$ \\
\hline
\end{tabular}

\section{Statistical analysis}

We used R (R Core Team 2012) and Ime4 (Bates et al. 2015) to create a linear mixedeffects model to analyze the relationship between the scores (1-6) given to the 20 motivations and the group of actors (biodiversity or non-biodiversity) and whether they scored for their main interest or nature activities. Three comparisons were made, as explained above. The relevant datasets were selected each time before the model was 
run, making for three different datasets as input. In the model, group was a fixed factor, while individual interviewees were regarded as a factor with random intercepts, because individual interviewees may rank motivations generally higher or lower than other interviewees. The model reads as 'Imer (score motivation*group $+(1 \mid$ interviewee)', with (1|interviewee) referring to the random factor. We ran the model once for each of the three comparisons, and in each run t-values were generated for how each motivation differs in score between the two groups that we selected for. Due to the random factor of the individual interviewees, the degrees of freedom were no longer well defined, which makes it impossible to properly estimate the p-values. However, we considered t-values lower than -2 and higher than 2 as critical values to indicate a significant difference between the scores, as these values correspond to $p<0.05$.

For investigating the general effect of group, gender and country, we used the approach of testing two models against each other with an ANOVA test. One model would include the fixed factor for gender or country, and the second model would not include this factor. A chi-square test showed whether significant differences existed between the models. All the interactions between the fixed factors were included in the model.

\section{RESULTS}

In the ranking of motivations of biodiversity activists, the ten highest ranking motivations differed little in their scores (Fig. 1a). This suggests that conservation action is founded on a broad selection of possible motivations. High ranking motivations were curiosity and learning, value of nature in itself, living a worthwhile life and future generations, 
which also showed the lowest deviations in their scores. The motivations personal benefit and self-significance received a low rating, as did anger, control and insecurity. Religion or spirituality and destiny also received a low rating on average. However, a high standard deviation for religion or spirituality indicated that this motivation often received either a high or low score.

a.

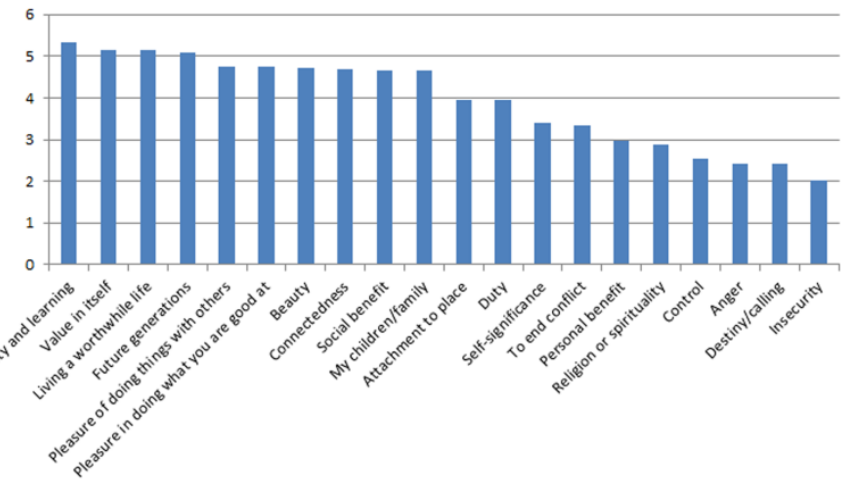

b.

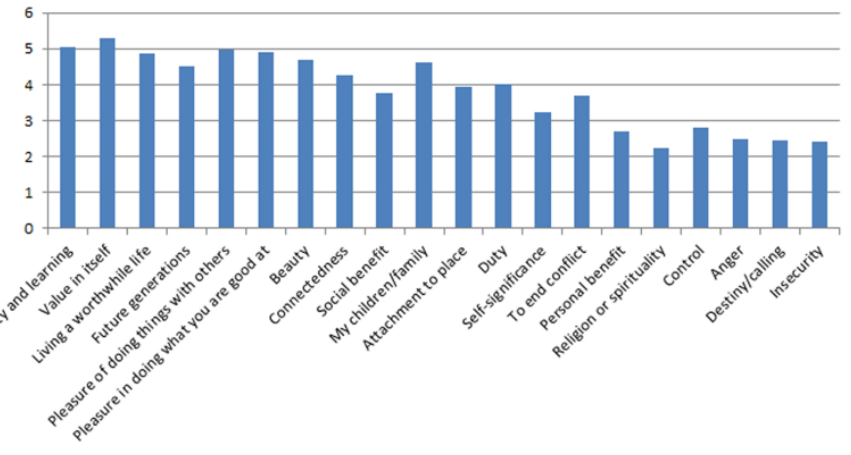

c.

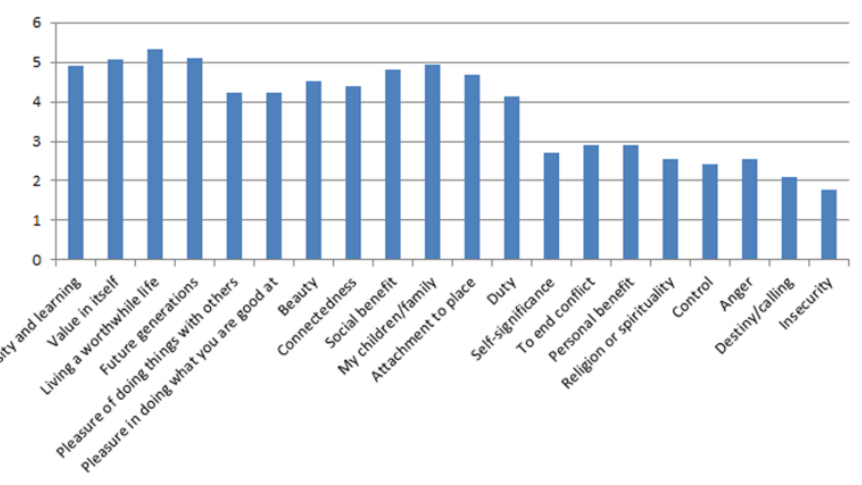


Figure 1 Motivations of biodiversity and non-biodiversity activists for their main interests and actions for biodiversity. The bars represent average values given to motivations by the interviewees. (a) Values given by biodiversity activists. (b) Values given by non-biodiversity activists for their main cause. (c) Values given by non-biodiversity activists for biodiversity action.

The rankings for main interest differed between the two groups (biodiversity cause versus non-biodiversity cause) (Likelihood Ratio Test, $\mathrm{Chi}^{2}=54.996, \mathrm{df}=20, \mathrm{p}<0.001$ ), although most motivations were rated similarly high or low between the two groups (Fig. 1). More precisely, value in itself, beauty and religion or spirituality were rated lower by the non-biodiversity activists for their main cause than by the biodiversity activists for their biodiversity cause (Table 2). This indicates that value in itself and beauty played generally more important roles in motivation when biodiversity conservation is the topic of interest. Religion or spirituality, however, had a low rating relative to the other motivations, indicating that it played a smaller role in general. 
Table 2. Motivation rankings, with t-values in bold and standard deviations between brackets. An asterisk $\left({ }^{*}\right)$ signifies a significant difference of a t-value $<-2$ and $>2$.

\begin{tabular}{|c|c|c|c|c|c|c|}
\hline \multirow[t]{2}{*}{$\begin{array}{l}\text { Motivation (as } \\
\text { presented on card) }\end{array}$} & \multirow{2}{*}{$\begin{array}{l}\text { Biodiversity } \\
\text { activists } \\
\begin{array}{l}\text { Average (and } \\
\text { standard } \\
\text { deviation) }\end{array}\end{array}$} & \multicolumn{2}{|c|}{$\begin{array}{l}\text { Non-biodiversity actors (topic } \\
\text { main interest) }\end{array}$} & \multicolumn{3}{|c|}{ Non-biodiversity actors (topic biodiversity) } \\
\hline & & $\begin{array}{l}\text { Average (and } \\
\text { standard } \\
\text { deviation) }\end{array}$ & $\begin{array}{l}\text { T value vs } \\
\text { Biodiversity } \\
\text { activists }\end{array}$ & $\begin{array}{l}\text { Average (and } \\
\text { standard } \\
\text { deviation) }\end{array}$ & $\begin{array}{l}\text { T value vs } \\
\text { Biodiversity } \\
\text { activists }\end{array}$ & $\begin{array}{l}\text { T value vs } \\
\text { Non- } \\
\text { biodiversity } \\
\text { actors (main } \\
\text { interest) }\end{array}$ \\
\hline $\begin{array}{l}\text { Curiosity and } \\
\text { learning }\end{array}$ & $5.29(1.04)$ & $5.04(1.12)$ & -0.885 & $4.89(1.20)$ & -1.587 & -0.533 \\
\hline $\begin{array}{l}\text { Living a worthwhile } \\
\text { life }\end{array}$ & $5.20(1.02)$ & $5.28(0.93)$ & 0.223 & $5.08(1.14)$ & -0.513 & -0.656 \\
\hline Future generations & $5.14(0.94)$ & $4.87(1.07)$ & -0.902 & $5.32(0.82)$ & 0.334 & 0.978 \\
\hline Value in itself & $5.07(1.00)$ & $4.50(1.34)$ & $-2.022 *$ & $5.11(1.13)$ & -0.467 & 1.350 \\
\hline $\begin{array}{l}\text { Pleasure of doing } \\
\text { things with others }\end{array}$ & $4.75(1.00)$ & $4.96(1.22)$ & 0.642 & $4.24(1.44)$ & -1.749 & -1.915 \\
\hline $\begin{array}{l}\text { Pleasure in doing } \\
\text { what you are good } \\
\text { at }\end{array}$ & $4.74(1.30)$ & $4.90(1.24)$ & 0.408 & $4.24(1.74)$ & -1.721 & -1.767 \\
\hline Social benefit & $4.71(1.22)$ & $4.69(1.46)$ & -0.14 & $4.51(1.43)$ & -0.762 & -0.583 \\
\hline My children/family & $4.71(1.42)$ & $4.27(1.75)$ & -1.473 & $4.38(1.69)$ & -1.028 & 0.116 \\
\hline Beauty & $4.68(1.26)$ & $3.76(1.65)$ & $-3.358^{*}$ & $4.81(1.61)$ & -0.155 & 2.438* \\
\hline Connectedness & $4.61(1.35)$ & $4.63(1.24)$ & -0.023 & $4.95(1.03)$ & 0.303 & 0.633 \\
\hline $\begin{array}{l}\text { Attachment to } \\
\text { place }\end{array}$ & $3.91(1.58)$ & $3.94(1.74)$ & -0.073 & $4.68(1.60)$ & 1.535 & 1.661 \\
\hline Duty & $3.89(1.56)$ & $4.00(1.55)$ & 0.428 & $4.14(1.70)$ & 0.305 & 0.184 \\
\hline To end conflict & $3.49(1.71)$ & $3.22(1.60)$ & -0.995 & $2.70(1.54)$ & $-2.167^{*}$ & -1.443 \\
\hline Self-significance & $3.36(1.33)$ & $3.69(1.39)$ & 1.105 & $2.891 .45)$ & -1.674 & $-2.119 *$ \\
\hline personal benefit & $2.96(1.49)$ & $2.71(1.59)$ & -0.856 & $2.89(2.00)$ & -0.533 & 0.278 \\
\hline $\begin{array}{l}\text { Religion or } \\
\text { spirituality }\end{array}$ & $2.91(1.71)$ & $2.22(1.70)$ & $-2.371 *$ & $2.54(1.77)$ & -1.249 & 0.627 \\
\hline Control & $2.54(1.34)$ & $2.81(1.58)$ & 0.725 & $2.41(1.71)$ & -0.78 & -1.145 \\
\hline Anger & $2.46(1.48)$ & $2.48(1.72)$ & 0.074 & $2.54(1.64)$ & 0.45 & 0.266 \\
\hline Destiny/calling & $2.41(1.47)$ & $2.45(1.60)$ & -0.053 & $2.11(1.47)$ & -1.251 & -1.005 \\
\hline Insecurity & 2.04 (1.17) & $2.40(1.54)$ & 1.154 & $1.78(1.11)$ & -0.984 & -1.685 \\
\hline
\end{tabular}


The follow-up question addressed the motivations that were important for nonbiodiversity activists for biodiversity conservation (Fig. 1c). In general, significant differences existed between the two groups for the motivations to act for biodiversity (Likelihood Ratio Test, $\mathrm{Chi}^{2}=33.694, \mathrm{df}=20, \mathrm{p}=0.028$ ). More specifically, the highest rated motivations were very similar between the two groups, but the to end conflict motive was rated lower (Fig. 2). This suggests that non-biodiversity activists may feel less driven to deal with conflicts involving biodiversity conservation. Yet, in comparison with the motivations for their main interest (Likelihood Ratio Test, $\mathrm{Chi}^{2}=60.945, \mathrm{df}=20$, $p<0.001$ ), for the non-biodiversity activists, beauty was an important motive to act for biodiversity as well, as they ranked it higher for biodiversity conservation than for their main interests (Table 2). No comparable difference was seen in the ratings for value in itself and religion or spirituality for biodiversity conservation, suggesting that these motivations were less important for this group for biodiversity conservation. Selfsignificance received lower scores for biodiversity conservation.

In summary, while both groups are very similar in their highest-ranking motivations, the biodiversity activists felt a greater affinity for the motivations value in itself and occasionally for religion or spirituality. The non-biodiversity activists felt great affinity for beauty regarding actions for biodiversity, in contrast to their main interest, and this affinity was also echoed by the biodiversity activists. However, the non-biodiversity actors differed from the activists in that the motivations of to end conflict and selfsignificance drop for actions for biodiversity. 


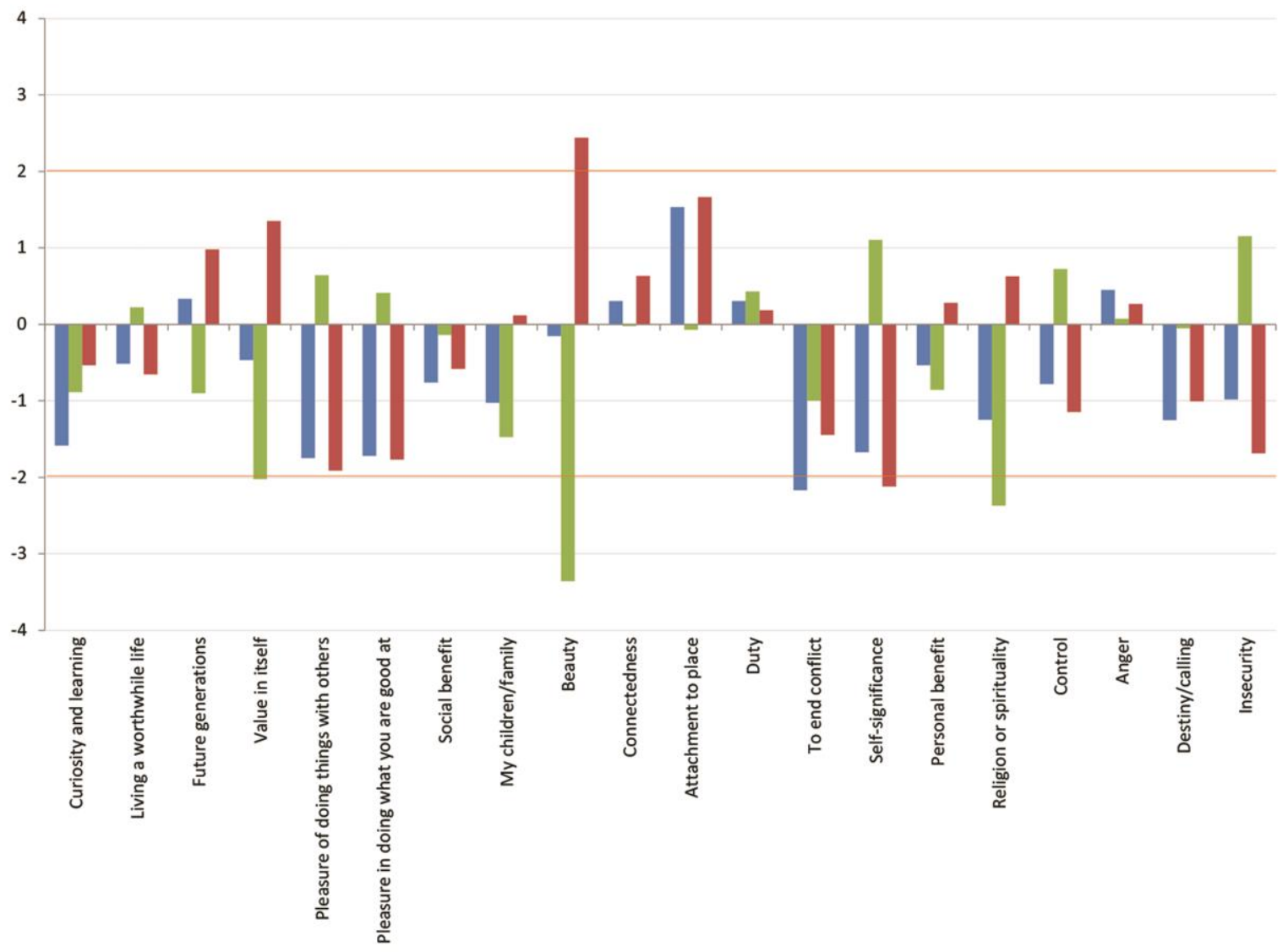

Figure $2 t$-values of the comparisons of motivation rankings. Dashed lines delimit the values of greater than +2 and less than -2 , signifying significant difference. Light grey bars represent the values of biodiversity activists versus non-biodiversity activists for biodiversity action. Dark grey bars represent the values of biodiversity activists versus non-biodiversity activists for their main cause. Black bars represent the values of non-biodiversity activists for their main cause versus biodiversity action.

No significant effect of gender was found in the model between the two groups and their rankings of motivations for their main interest $(p=0.2154)$, nor for biodiversity conservation $(p=0.8811)$. Nor within the non-biodiversity activists between main interest and biodiversity conservation $(\mathrm{p}=0.1488)$. There was a country effect between the two 
groups for their main interest (Likelihood Ratio Test, $\mathrm{Chi}^{2}=423.95, \mathrm{df}=240, \mathrm{p}<0.001$ ).

The greatest differences among countries were found in the ratings of Germany and the UK, whose non-biodiversity activists scored the highest for many motivations. However, the motivations value in itself, beauty and religion or spirituality, which differed the most in the total comparison (Fig. 2), were ranked similarly among the countries; the average ranking between countries might therefore differ, but the same motivations were rated differently between the groups in all countries.

\section{DISCUSSION}

\section{Overview}

Although the rankings by biodiversity activists for their conservation work differ significantly from the rankings by non-biodiversity activists for their main interests, a deeper investigation clarifies that only a few specific motivations show a significant difference between these two groups, and the top and bottom motivations are very similar in both groups (figure 2). This suggest not only that biodiversity conservation is supported by a broad palette of motivations, but also that this palette of motivations for committed action is shared amongst people regardless of the topic of interest. The similarities in ratings between the countries further underscore a universality of these motivations. Although our list of motivations was unstructured in setup, we interpreted the four top ranking motivations as values, following the scheme of environmental values by Muraca (2011), according to whom the worthwhile life motivation can be seen as a relational value, next to moral values. These four top ranking motivations could be interpreted as aggregating into two groups: $(I)$ living a meaningful life (living a worthwhile 
life and curiosity and learning) and (ii) moral values (future generations and value in itself). We explore this broad palette more deeply underneath.

The motivations referring to living a meaningful life make a set of values explicit that have been called eudaemonistic, and differ from hedonic or moral values (Muraca 2011) and from welfare maximization in neo-classical economics (O'Neill \& Spash 2000). The notion of eudaemonistic value can be traced back to Aristotle and originally referred to the obligation of every human to "live in truth to his or her daemon," a kind of inner voice speaking about good or bad (Norton 1976). The concept is still used in literature on motivation (Ryff \& Singer 2008) and also appears in the 'quest for significance' theory of Kruglanski et al. (2009). Ryan et al. (2008) define the meaningful life as self-realization. In environmental psychology, analogous concepts surface in environmental self-identity (Van der Werff et al. 2013) and ecological responsibility (Jagers \& Matti 2010), which refers to how people regard themselves and their environmental behavior.

The motivations value in itself and future generations refer to moral values. The public perceptions of nature's value in itself, often called intrinsic value, have been investigated before in European countries (Grendstad \& Wollebaek 1998; Butler \& Acott 2007; Van den Born 2008), leading to the consensus that the great majority of people recognize the intrinsic value of nature. This is corroborated by research into human-nature relationships. As shown by Kempton et al. (1995) and De Groot \& Van den Born (2007), respondents show high levels of adherence to ecocentric stewardship in which people are seen as part of nature, responsible for taking care of nature and for preserving nature for future generations. 
For the non-biodiversity activists, motivations to be involved in biodiversity conservation are largely the same as for the biodiversity activists in that future generations, value in itself and living a worthwhile life are rated highly. However, in comparison to the biodiversity activists, the motivations of to end conflict and self-significance have less importance for non-biodiversity actors for these activities. Possibly, non-biodiversity activists already achieve a sense of self-significance through their main non-biodiversity interest. In contrast, the motivation beauty appeared to be very important for their biodiversity actions and less important for their main interest. These findings suggest that the discovery of beauty and values in nature may be foundational for less committed actors to act for biodiversity. Richards (2001) has argued how beauty could support environmental awareness. Stimulating biodiversity actions amongst non-biodiversity activists may require a strong focus on beauty in addition to the four highest ranking motivations.

\section{Limitations}

The method used has some limitations. First, the cards may have been interpreted differently. One example is the description of the connectedness card, which refers to "connectedness with a larger whole" and might have been too esoteric for respondents. This may explain why scores for connectedness are lower than expected. Connectedness has been introduced before as a key motivational drive (Tam 2013; Nolt 2006), and a feeling of connectedness with nature may underlie many other motivations. Also, the motivation to end conflict created some confusion, because its relevance to biodiversity conservation was occasionally unclear. Issues of interpretation were 
addressed during the interviews by asking interviewees for their interpretations and explaining to them the interpretations that were agreed upon at the workshop.

Secondly, some cards describe values, other emotional states and yet others emphasize end goals. It is unclear how much this lack of homogeneity in the list influenced the ranking by respondents (cf. Ryan et al. 2008). This limitation is a consequence of the broad selection of motivations in our list, which was meant to reflect the full breadth of knowledge in the literature. It enabled the recognition of important motivations that otherwise might have gone undetected, such as the role of eudaimonistic values, which is thus far neglected in motivation research for nature conservation. Also, social relations and conflicts of interest that may be very relevant in real-life situations are not covered in the card ranking method, and some motivations carry positive or negative associations, which may influence the ranking of some cards, such as living a worthwhile life, personal benefit and insecurity. Nevertheless, the results offer an inroad for follow-up research on the context of motivation, such as life history, and the possible existence of different types of activists and their relations to affiliations or groups of motivations.

Finally, because our data was gathered only in European countries, it is unclear whether our data are generalizable to other regions. However, experiences of successful conservation in Europe are of interest to other regions who follow similar developmental paths (Boitani \& Sutherland 2015). The selection procedure identified committed actors who operated successfully within many different social environments. This successful embedding of conservation within social environments and the motivations that support 
this, such as working for future generations and pleasure of working with others may be important in other regions as well.

\section{Policy relevance}

Ecosystem services are communicated in policy increasingly as the main reasons to act for biodiversity. Although motivations such as curiosity and learning, value in itself, living a worthwhile life and beauty can be connected to 'cultural ecosystem services' such as spiritual services (MEA 2005), and groupings of ecosystem services appear to be connected with different values (Hicks et al. 2015), a back-translation from services to motivation appears to be problematic for stimulating conservation. The functionalistic outlook of the ecosystem services concept, in which biodiversity produces services for society, may be inappropriate to express and stimulate motivations to act, as humannature relationships appear to be more complex than that (Flint et al. 2013).

Our results offer scope to address this limitation of ecosystem services to stimulate motivation for biodiversity conservation. First, the highest ranking motivations driving biodiversity activists - curiosity and learning about nature, seeing conservation as a part of living a meaningful life, caring for future generations, and nature's intrinsic value should be recognized and supported in order to stimulate their ongoing activities and the growth of new young conservation enthusiasts. Secondly, to involve actors from other sectors, a slightly different set of motivations may be addressed, including a stronger focus on natural beauty. 
This study shows that people act for biodiversity mainly out of eudaimonistic and moral values. Ecosystem services itself may provide an initial inspiration to get more people on board, but is limited in motivating conservation leaders and does not halt biodiversity loss on its own. Acknowledging the full gamut of motivations is necessary to inspire conservation leaders and get more people to act for nature conservation. An improved policy basis for motivating biodiversity conservation would therefore consist of three elements: (I) nature as meaningful in the lives of people, (ii) nature as having intrinsic values and (iii) nature delivering ecosystem services. Advertising only the services of nature offers a weak and possibly even counter-productive basis for large-scale individual action for biodiversity.

\section{SUPPLEMENTARY MATERIAL}

For supplementary material accompanying this paper, visit http://www.journals.cambridge.org/ENC

\section{ACKNOWLEDGEMENTS}

This material is based on work supported by the European Research Council under FP7 Grant Agreement FP7 282625, BIOMOT: MOTivational strength of ecosystem services and alternative ways to express the value of BIOdiversity. The authors are grateful to the interviewees who participated in this study.

\section{FINANCIAL SUPPORT}

This research was supported by FP7 Grant Agreement 282625, BIOMOT: Motivational strength of ecosystem services and alternative ways to express the value of biodiversity. 
CONFLICT OF INTEREST

None. 


\section{REFERENCES}

- Admiraal, J.F., Musters, C.J.M. \& de Snoo, G.R. (2016) The loss of biodiversity conservation in EU research programmes: Thematic shifts in biodiversity wording in the environment themes of EU research programmes FP7 and Horizon 2020. Journal for Nature Conservation 30: 12-18.

- Asah, S.T. \& Blahna, D.J. (2013) Practical Implications of Understanding the Influence of Motivations on Commitment to Voluntary Urban Conservation Stewardship. Conservation Biology 27: 866-875.

- Bates, D., Maechler, M., Bolker, B. \& Walker, S. (2015) Ime4: Linear mixedeffects models using Eigen and S4. R package version 1.1-9. [www document] URL https://CRAN.R-project.org/package=Ime4

- BIOMOT (2011) Motivational strength of ecosystem services and alternative ways to express the value of biodiversity, FP7-ENV-2011-282743. [www document] URL http://www.biomotivation.eu/

- BIOMOT (2013) Motivation for Biodiversity Action: Vocabulary, Theories and Framework. Knippenberg L (ed.). [www document] URL http://www.biomotivation.eu/docs/BIOMOT CC document July 2013.pdf

- Boitani, L., \& Sutherland, W.J. (2015) Conservation in Europe as a model for emerging conservation issues Globally. Conservation Biology DOI: 10.1111/cobi.12530. 
- van den Born, R.J.G., Lenders, R.H.J., De Groot, W.T. \& E. Huijsman (2001) The New Biophilia: An exploration of visions of nature in Western countries. Environmental Conservation 28: 65-75.

- van den Born R.J.G. (2008) Rethinking Nature: Public Visions in the Netherlands. Environmental Values 17: 83-109.

- Butler, W.F. \& Acott ,T.G. (2007) An Inquiry Concerning the Acceptance of Intrinsic Value Theories of Nature. Environmental Values 16: 149-168.

- Carrus, G., Passafaro, P. \& Bonnes, M. (2008) Emotions, habits and rational choices in ecological behaviours: The case of recycling and use of public transportation. Journal of Environmental Psychology 28: 51-62.

- Clark, C.F., Kotchen, M.J. \& Moore, M.R. (2003) Internal and external influences on pro-environmental behavior: Participation in a green electricity program. Journal of Environmental Psychology 23: 237-246.

- Corral-Verdugo, V., Fraijo-Sing, B. \& Pinheiro, J.Q. (2006) Sustainable Behavior and Time Perspective: Present, Past, and Future Orientations and Their Relationship with Water Conservation Behavior. Revista Interamericana de Psicología/Interamerican Journal of Psychology 40: 139-147.

- Costanza, R., dArge, R., de Groot, R., Farber, S., Grasso, M., Hannon, B., Limburg, K., Naeem, S., O'Neill, R.V., Paruelo, J., Raskin, R.G., Sutton, P. \& vandenBelt, M. (1997) The value of the world's ecosystem services and natural capital. Nature 387: 253-260.

- Dedeurwaerdere, T., Admiraal, J.F., Beringer, A., Bonaiuto, F., Cicero, L., Fernandez-Wulff, P., Hagens, J., Hiedanpaa, J., Knights, P., Molinario, E., 
Melindi-Ghidi, P., Popa, F., Silc, U., Soethe, N., Soininen, T. \& Vivero, J.L. (2016)

Combining internal and external motivations in multi-actor governance arrangements for biodiversity and ecosystem services. Environmental Science \& Policy 58: 1-10.

- EEA (2015) State of nature in the EU; Results from reporting under the nature directives 2007-2012. EEA (European Environment Agency). [www document] URL http://www.eea.europa.eu/publications/state-of-nature-in-the-eu

- EU (2015) Special Eurobarometer 436 "Attitudes of Europeans towards biodiversity”. DOI: 10.2779/832333.

- Flint, C.G., Kunze, I., Muhar, A., Yoshida, Y. \& Penker, M. (2013) Exploring empirical typologies of human-nature relationships and linkages to the ecosystem services concept. Landscape and Urban Planning 120: 208-217.

- Fiske, S.T. (2014) Social beings: A core motives approach to social psychology. 4th edition. Wiley, New York.

- Gifford, R. \& Nilsson, A. (2014) Personal and social factors that influence proenvironmental concern and behaviour: A review. International Journal of Psychology 49: 141-157.

- Gómez-Baggethun, E. \& Ruiz-Pérez, M. (2011) Economic valuation and the commodification of ecosystem services. Progress in Physical Geography 35: 613628.

- Grendstad, G., Wollebaek, D. (1998) Greener still? An empirical examination of Eckersley’s ecocentric approach. Environment \& Behavior 30: 653-675. 
- de Groot, M. \& Van den Born R.J.G. (2007) Humans, nature and god: exploring images of their interrelationships in Victoria, Canada. Worldviews: Global Religions, Culture, and Ecology 11: 324-351.

- Hicks, C.C., Cinner, J.E., Stoeckl, N. \& McClanahan, T.R. (2015) Linking ecosystem services and human-values theory. Conservation Biology 29: 14711480.

- Hiedanpää, J. \& Borgström, S. (2014) Why do some institutional arrangements succeed? Voluntary protection of forest biodiversity in Southwestern Finland and of the Golden Eagle in Finnish Lapland. Nature Conservation 7: 29-50.

- IPBES (2015) The Intergovernmental Science-Policy Platform on Biodiversity and Ecosystem Services. [www document] URL http://www.ipbes.net/about-us

- Jagers, S.C. \& Matti, S. (2010) Ecological Citizens: Identifying Values and Beliefs that Support Individual Environmental Responsibility among Swedes. Sustainability 2: 1055-1079.

- Kempton, W., Boster, J.S. \& Hartley, J.A. (1995) Environmental Values in American Culture. The MIT Press, Cambridge, MA.

- Kollmuss, A. \& Agyeman, J. (2002) Mind the Gap: Why do people act environmentally and what are the barriers to pro-environmental behavior? Environmental Education Research 8: 239-260.

- Kruglanski, A.W., Chen, X., Dechesne, M., Fishman, S. \& Orehek, E. (2009) Fully Committed: Suicide Bombers' Motivation and the Quest for Personal Significance. Political Psychology 30: 331-557. 
- Locatelli, B., Imbach, P. \& Wunder, S. (2013) Synergies and trade-offs between ecosystem services in Costa Rica. Environmental Conservation 41: 27-36.

- Mayer, F.S. \& Frantz, C.M. (2004) The connectedness to nature scale: A measure of individuals' feeling in community with nature. Journal of environmental psychology 24: 503-515.

- MEA (2005) Millennium ecosystem assessment. Island Press, Washington, D.C., USA.

- Muraca, B. (2011) The Map of Moral Significance: a new matrix for environmental ethics. Environmental Values 20: 375-396.

- Nolt, J. (2006) The Move from Good to Ought in Environmental Ethics. Environmental Ethics 28: 355-374.

- Norgaard, R.B. (2010) Ecosystem services: from eye-opening metaphor to complexity blinder. Ecological Economics 69, 1219-1227.

- Norton, D. (1976) Personal Destinies: A Philosophy of Ethical Individualism. Princeton university Press, Princeton, New Jersey, USA.

- O'Neill, J. (1997) Managing without prices: the monetary valuation of biodiversity. Ambo 26: 546-50.

- O'Neill, J. \& Spash, C.L. (2000) Conceptions of Value in Environmental DecisionMaking. Environmental Values 9: 521-36

- Pearce, D. (2007) Do we really care about Biodiversity? Environmental and Resource Economics 37: 313-333.

- Perkins, H.E. (2010) Measuring love and care for nature. Journal of Environmental Psychology 30: 455-463. 
- R Core Team (2012) R: A language and environment for statistical computing. R Foundation for Statistical Computing, Vienna, Austria.

- Richards, R. (2001) A new aesthetic for environmental awareness: chaos theory, the beauty of nature, and our broader humanistic identity. Journal of Humanistic Psychology 41: 59-95.

- Rode, J., Gómez-Baggethun, E. \& Krause, T. (2015) Motivation crowding by economic incentives in conservation policy: A review of the empirical evidence. Ecological Economics 109: 270-282.

- Ryan, R.M. \& Deci, E.L. (2000) Self-determination theory and the facilitation of intrinsic motivation, social development, and well-being. American Psychologist 55: 68-78.

- Ryan, R.M., Huta. V. \& Deci, E.L. (2008) Living well: a-self-determination theory perspective on eudaimonia. Journal of Happiness Studies 9: 139-170.

- Ryff, C.D. \& Singer, B.H. (2008) Know thyself and become what you are: a eudaimonic approach to psychological well-being. Journal of Happiness Studies 9: 13-38.

- Schultz, P.W. (2000) Empathizing with Nature: The effects of perspective taking on concern for environmental issues. Journal of Social Issues 56: 391-406.

- Schultz, P.W. (2001) The structure of environmental concern: Concern for self, other people, and the biosphere. Journal of Environmental Psychology 21: 327339. 
- Schwartz, S.H. (1992) Universals in the content and structure of values: theoretical advances and empirical tests in 20 countries. Advances in experimental social psychology 25: 1-65.

- Sponarski, C.C., Vaske, J.J., Bath, A.J. \& Musiani, M.M. (2014) Salient values, social trust, and attitudes toward wolf management in south-western Alberta, Canada. Environmental Conservation 41: 303-310.

- Tam, K.P. (2013) Concepts and measures related to connection to nature: Similarities and Differences. Journal of Environmental Psychology 34: 64-78.

- TEEB (2013) The Economics of Ecosystems and Biodiversity. A synthesis of approaches to assess and value ecosystem services in the EU in the context ofTEEB. [www document] URL http://ec.europa.eu/environment/nature/biodiversity/economics

- Tittensor, D.P., et al. (2014) A mid-term analysis of progress toward international biodiversity targets. Science 346: 241-244.

- van der Werff, E., Steg, L. \& Keizer, K. (2013) The value of environmental selfidentity: The relationship between biospheric values, environmental self-identity and environmental preferences, intentions and behavior. Journal of Environmental Psychology 34: 55-63.

- Williams, D.R. \& Vaske, J.J. (2003) The measurement of place attachment: validity and generalizability of a psychometric approach. Forest Science 49: 830840. 